American Journal of Agricultural and Biological Sciences 3 (2): 490-493, 2008

ISSN 1557-4989

(C) 2008 Science Publications

\title{
Improving a PCR-Based Method for Identification of Ralstonia solanacearum in Natural Sources of West Malaysia
}

\author{
${ }^{1}$ Reza Khakvar, ${ }^{1}$ Kamaruzaman Sijam, ${ }^{1}$ Wong Mui Yun, ${ }^{2}$ Son Radu and ${ }^{3}$ Thong Kwai Lin \\ ${ }^{1}$ Department of Plant Protection, Faculty of Agriculture \\ ${ }^{2}$ Department of Food Science, Faculty of Food Science and Technology, \\ University Putra Malaysia (UPM), \\ ${ }^{3}$ Institute of Biological Sciences, \\ Faculty of Science, University Malaya (UM), Selangor, Malaysia
}

\begin{abstract}
Ralstonia solanacearum, a soil-borne plant pathogen, causes lethal wilting disease of more than 200 plants worldwide. This very wide host range covers both monocots and dicots, extending from annual plants to trees and shrubs. Although generally it's considered as a plant pathogen, $R$. solanacearum behaves primarily as a saprophytic bacterium able to survive for long periods of time in various natural habitats such as surface waters and different types of soils. Epidemiological and ecological studies on pathogen distribution in the environment are seriously hindered by the lack of efficient detection method especially when the concentration of the pathogen is either very low or is present in a latent, dormant or non-culturable state. With due attention to importance of $R$. solanacearum in Malaysia and several irreparable losses that every year caused by this bacterium, this is prompted current study to develop a sensitive PCR-Based method to improve the detection of $R$. solanacearum in natural sources. We selected the previously reported primers (OLI1;OLI2; Y2; JE2) for their sensitivity and specificity detection of the bacterium in water and soil by a modification of PCR assay.
\end{abstract}

Key words: Ralstonia solanacearum, bacteria, PCR and West Malaysia

\section{INRODUCTION}

Ralstonia solanacearum, previously known as Pseudomonas solanacearum (Smith, 1896), in the Proteobacteria $\beta$ subdivision is a plant pathogenic bacterium commonly found in the soils of tropical and subtropical countries where it devastates cultivation of many crop plants ${ }^{[1,2]}$. This organism, responsible for bacterial wilts, can infect over 300 plant species belonging to over 30 botanical families ${ }^{[3]}$. Major agricultural hosts include tobacco, tomato, potato, eggplant, chili and banana trees ${ }^{[4]}$. Weeds appear as alternative hosts for the pathogen to survive in the absence of its susceptible host plants ${ }^{[3]}$. Field symptoms of this bacterium are rapid and irreversible wilt under favorable conditions, stunting and yellowing of foliage ${ }^{[1]}$. Epidemiological and ecological study of $R$. solanacearum is difficult because the pathogen has an extremely broad host range and is able to survive in the soil in the absence of the host plant ${ }^{[1]}$. Moreover, it can colonize host plants like members of the Solanaceae and non-host plants including many weeds, without producing any visible symptom ${ }^{[3]}$. $R$. solanacearum can persist at low populations in naturally infested soil for years without a host plant and the population size could increase to the plant infection threshold within a season after the host plants are returned to the fields ${ }^{[3]}$. Therefore, early detection of the bacterium in soil, water, weeds, tubers and plant residues could facilitate elimination and certainly reduce the risk of crop loss. However, the commonly used methods such as isolation on semi-selective medium, serological methods (ELISA or immunofluorescence), or pathogenicity tests on host plants for the diagnosis of bacterial wilt are often inadequate in terms of specificity, sensitivity or response time, especially for detecting the bacterium in soil and water ${ }^{[5]}$. In order to optimize the efficiency of prophylactic measures, powerful tools for the identification and detection of the bacterium in diverse substrates (plant, seed, water \& soil) are required. DNA amplification pathogen offers many advantages over classical techniques; neither purification nor cultivation of the pathogen are required and the specificity,

Corresponding Author: Reza Khakvar, Department of Plant Protection, Faculty of Agriculture, University Putra Malaysia, 43400, Serdang, Selangor, Malaysia Tel: $+603-89466986$ Fax: $+603-86560690$ 
sensitivity and response time of tests are improved. Nevertheless, the PCR method has not yet become a routine diagnostic tool for many laboratories, mainly because of the inhibition of the amplification reaction by compounds contained in crude bacterial extracts, which give false negative results or low detection sensitivity ${ }^{[6,7,8]}$. Until now there is a very few validated PCR protocol recommended for the detection of $R$. solanacearum in samples especially in soil and water samples. Therefore, this study was to develop and compare several procedures to overcome PCR inhibition problems and to propose a set of standard protocols for reliable detection of $R$. solanacearum whatever the origin of the sample.

\section{MATERIALS AND METHODS}

Bacterial sample collection: Field soil samples used for this study were collected from banana, tomato, chili, eggplant and tobacco fields in West Malaysia. Samples were collected randomly, at a depth of 5 to $30 \mathrm{~cm}$, to form a composite sample for each unit ${ }^{[9]}$. At each unit, $10 \mathrm{~g}$ of soil were taken to make a $100 \mathrm{ml}$-soil suspension for detection. Irrigation water samples were collected from same fields or from water canals in same area. Water samples were collected $(50 \mathrm{~mL}$ per sample) at the entrance and exit spots of the irrigation ditches for each field. All field samples were maintained at $4^{\circ} \mathrm{C}$ in plastic bags during transportation and storage before testing.

Improved bacterial DNA extraction: All soil samples were crushed and suspended by blinder using Tris buffer $(100 \mathrm{mM})$. One milliliter of supernatant from each suspension (and water samples directly) was added to $9 \mathrm{~mL}$ of liquid SMAS medium (SMSA without agar). The cultures was incubated at $30^{\circ} \mathrm{C}$ with $150 \mathrm{rpm}$ for $24 \mathrm{~h}$. After enrichment, $5 \mathrm{~mL}$ of enriched cultures were placed in $200 \mathrm{~mL}$-tubes and placed into a boiling water bath for $5 \mathrm{~min}$. After a low speed centrifuge $(1500 \mathrm{rpm}, 5 \mathrm{~min})$, the supernatant was transferred to a new microfuge tube and equal volume of phenol:chloroform:isoamyl alcohol (25:24:1; pH 7.6) was added, which they were mixed by vortexing at the maximum speed for $1 \mathrm{~min}$ and centrifuged at $16000 \mathrm{~g}$ for $10 \mathrm{~min}$. The aqueous phase was transferred to new tube and 0.1 volume of $3 \mathrm{M}$ sodium acetate $(\mathrm{pH} 5.2)$ and 0.6 volume of isopropanol were added. The solution was mixed well and centrifuged at $16000 \mathrm{~g}$ for $15 \mathrm{~min}$. DNA pellets were washed with $70 \%$ ethanol twice, dried and resuspended in $20 \mu \mathrm{L}$ of TE (10 mM Tris, $1 \mathrm{mM}$ EDTA, pH 8.0) buffer.
Two microliter of this DNA solution were taken for PCR analysis. To compare the quality of this method with other methods, DNA extraction were performed for all samples using two other methods that already have been described by Elphinstone et al. ${ }^{[7]}$ and Pradhanang et al. ${ }^{[9]}$.

PCR amplification: The reaction was preformed in final volume of $25 \mu \mathrm{L}$ using primer pairs OLI-1/OLI-2 followed by Y2/JE2 according to nested PCR procedure detailed by Poussier and Luisetti ${ }^{[10]}$. Moreover, $0.5 \mathrm{ng} \mu \mathrm{L}^{-1}$ of BSA (Bovine serum albumin) were added to PCR mixture to prevent any inhibition effect on PCR. PCR products were analyzed by electrophoresis on $1 \%$ agarose gel and visualized UV light $(300 \mathrm{~nm})$ after Ethidium Bromide staining. Also conventional PCR was preformed with OLI-1/Y2 and JE2/OLI-2 according to Seal et al. ${ }^{[11]}$ and Elphinstone et al. ${ }^{[6]}$ respectively.

\section{Evaluation sensitivity of improved detection method} in natural samples: To determine the detection threshold of our improved method and compare it with other methods, bacterial suspension of $R$. solanacearum strain were prepared by making a 10 -fold dilution series from a liquid culture. Two bacterial strains that already had been confirmed as $R$. solanacearum were used for this experiment. Soil samples were spiked with these two strains by mixing each $100 \mathrm{~g}$ autoclaved soil with $10 \mathrm{~mL}$ of bacterial suspensions each containing from $10^{1}$ to $10^{8} \mathrm{CFU} \mathrm{mL} \mathrm{m}^{-1}$ bacteria. The inoculated soil samples were incubated at $28^{\circ} \mathrm{C}$ for $24 \mathrm{~h}$ prior testing. To determine detection threshold of $R$. solanacearum in water samples, $500 \mathrm{~mL}$ of autoclaved irrigation water were artificially contaminated by same serial dilutions of $R$. solanacearum strain, giving a final concentration

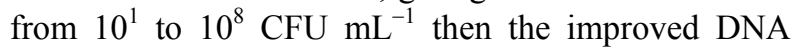
extraction method were applied to all samples. Before DNA extraction all sample were infested by some bacterial isolates that had been grown on TZC medium but have not been confirmed as $R$. solanacearum.

\section{RESULTS AND DISCUSSION}

Sample collection: A total of one hundred soil and water samples were collected from all parts of West Malaysia. The sampling sites were included vegetable farms and other production areas planted with known hosts of the pathogen, such as banana and tobacco. The presence of $R$. solanacearum in the soil or water of these areas already had been confirmed by Khakvar et al. [unpublished data]. 
PCR amplification: Both of the PCR methods (conventional and improved Nested-PCR) could detect $R$. solanacearum strains in samples. In our improved nested-PCR, in first step, a 410 bp amplicon was produced. Followed PCR (nested) produced a $220 \mathrm{bp}$ amplicon in sixty-nine samples. No other bands were observed in all samples. Conventional PCR with primers OLI-Y2 produced $280 \mathrm{bp}$ amplicon in 60 samples while a very weak band (90 bp) was observed in 12 of these samples. PCR with primer JE2-OLI produced a $340 \mathrm{bp}$ amplicon in 67 samples while in two of these samples two weak bands (48 and $390 \mathrm{bp}$ ) were observed. In 23 samples, no band was shown by both methods (Fig. 1).

Sensitivity threshold: The sensitivity of the individual PCR using the OLI1/OLI2/Y2/JE2 primers were measured with 10-fold dilution series of $R$. solanacearum samples that artificially were contaminated. The bacterium was detectable in samples as few as $10^{2}-10^{5} \mathrm{CFU} \mathrm{mL} \mathrm{mL}^{-1}$ in nested PCR without any non-target band. The sensitivity of detection with conventional PCR using OLI1/Y2 \& JE2/OLI2 nearly was same $\left(10^{4}-10^{5} \mathrm{CFU} \mathrm{mL}^{-1}\right)$ but some non-target bands were observed especially in soil samples (Table 1).
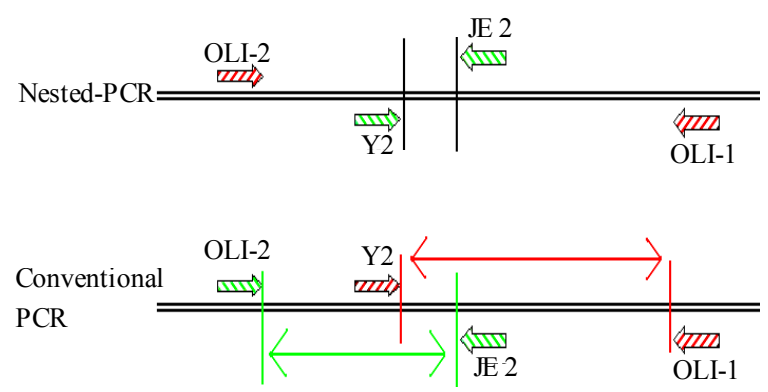

(a)

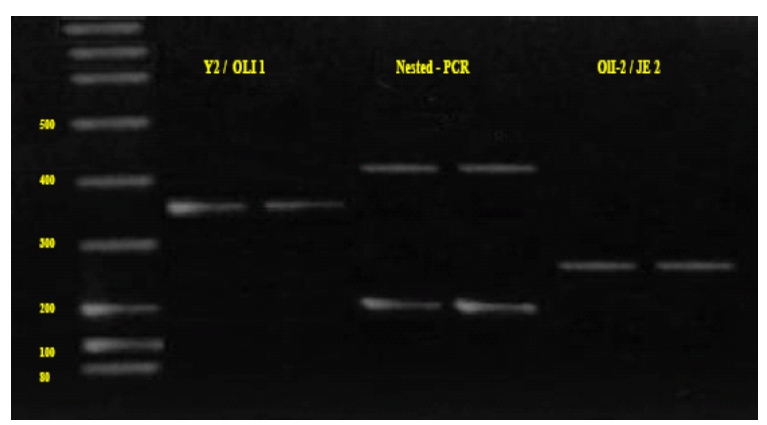

(b)

Fig. 1: (a): The primers with their positions that have been used for conventional and nested-PCR, (b): Results of conventional and nested-PCR
Table 1: Sensitivity and specificity of PCR reactions in R. solanacearum samples

\begin{tabular}{lllll}
\hline & $\begin{array}{l}\text { Sensitivity } \\
\text { in soil } \\
\text { sample }\end{array}$ & $\begin{array}{l}\text { Sensitivity } \\
\text { in water } \\
\text { sample }\end{array}$ & $\begin{array}{l}\text { Non-target } \\
\text { band in } \\
\text { positive } \\
\text { samples }\end{array}$ & $\begin{array}{l}\text { Non-target } \\
\text { band in } \\
\text { negative } \\
\text { samples }\end{array}$ \\
\hline Nested-PCR & $10^{3}-10^{5}$ & $10^{3}-10^{5}$ & - & - \\
OLI/Y2 & $10^{4}-10^{6}$ & $10^{4}-10^{6}$ & + & - \\
JE2/OLI2 & $10^{4}-10^{6}$ & $10^{4}-10^{6}$ & + & - \\
\hline
\end{tabular}

The results presented above demonstrate the development of an improved PCR-based assay capable of detection and identification of $R$. solanacearum directly in natural sources. In routine laboratory studies, $R$. solanacearum can be detected by conventional PCR assays in aqueous suspensions ranging from

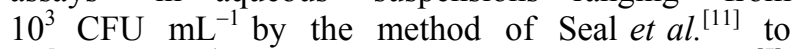
$10^{5} \mathrm{CFU} \mathrm{mL} \mathrm{mL}^{-1}$ by the method of Elphinstone et al. ${ }^{[7]}$. However, in plant samples, detection limit for former assay have been shown that can be increased to $10^{6}$ CFU mL ${ }^{-1}$ or higher due to low concentration of PCR inhibitor substances ${ }^{[12,13,14]}$. Previous studies have been shown that primers of OLI1, OLI2, Y2 and JE2 are not completely specific for species of $R$. solanacearum but nested-PCR using with these primers provide a very specific tool for differentiation of $R$. solanacearum strains in soil and water samples. Close detection threshold of conventional PCR and nested-PCR in this study shows that providing a suitable method for DNA extraction from samples is the first and the most important part of a reliable detection of Bacteria in samples. Bacterial DNA extraction in this study is shorter and more easier than previous methods ${ }^{[15]}$, therefore, this method can be used as a sufficient and reliable method for direct detection of $R$. solanacearum in water and soil samples.

\section{ACKNOWLEDGMENTS}

This research was supported by funding under Malaysian Technical Cooperation Program (MTCP) from Ministry of Higher Education of Malaysia and University Putra Malaysia (UPM).

We are grateful to Mrs. Junaina Jaafar, Mr. Zawawi Idris and Mr. Yusoff Mohd. Yassin from Laboratory of Microbiology and Mrs. N. Sabour from Environmental Sciences Dept. for their technical assistance.

\section{REFERENCE}

1. Agrios, R.E.F., 2005. Plant Pathology. 5th edn. Academic Press, pp: 920. 
2. CABI, EPPO., 1999. Distribution maps of plant diseases. Ralstonia solanacearum. Map Nos., 783-785. CAB International, Wallingford (GB).

3. Hayward, A.C., 1991. Biology and epidemiology of bacterial wilt caused by Pseudomonas solanacearum. Ann. Rev. Phytopathol., 29: 67-79.

4. Hooker, W.J., 1990. Compendium of potato diseases. American Phytopathology Society, St, Paul, Minnesota, pp: 125.

5. Lelliott, R.A. and D.E. Stead, 1987. Methods for the Diagnosis of Bacterial Diseases of Plants. Blackwell Scientific, Oxford, pp: 220.

6. Dittapongpitch, V. and S. Surat, 2003. Detection of Ralstonia solanacearum in soil and weeds from commercial tomato fields using Immunocapture and the polymerase chain reaction. J. Phytopathol., 151: 239-246.

7. Elphinstone, J.G., J. Hennessy, J.K. Wilson and D.E. Stead, 1996. Sensitivity of different methods for the detection of Ralstonia solanacearum. Bull. OEPP/EPPO., 26: 674-678.

8. Schaad, N.W., J.B. Jones and W. Chun, 2001. Laboratory Guide for Identification of Plant Pathogenic Bacteria. 3rd Edn. APS. St, Paul, Mn, pp: 245.

9. Pradhanang, P.M., J.G. Elphinstone and R.T.V. Fox, 2000. Sensitive detection of Ralstonia solanacearum in soil: A comparison of different detection techniques. Plant Pathol., 49: 414-422.
10. Poussier, S. and J. Luisetti, 2000. Specific detection of biovars of $R$. solanacearum in plant tissue by nested PCR. Eur. J. Plant Pathol., 106: 255-265.

11. Seal, S.E., L.A. Jackson, J.P.W. Young and M.J. Daniels, 1993. Differentiation of Pseudomonas solanacearum, Pseudomonas syzygii, Pseudomonas pickettii and the blood disease bacterium by partial 16S rRNA sequencing: Construction of oligonucleotide primers for sensitive detection by polymerase chain reaction. J. Gen. Microbiol., 139: 1587-1594.

12. Boudazin, G., A.C. Le Roux, K. Josi, P. Labarre and B. Jouan, 1999. Design of division-specific primers of Ralstonia solanacearum and application to the identification of European isolates. Eur. J. Plant Pathol., 105: 373- 380.

13. Anlee, Y. and C.C. Wang, 2000. Design of specific primers for detection of Ralstonia solanacearum in soil samples by polymerase chain reaction. Bull. Acad. Sin., 41: 121-128.

14. Pastrik, K.H. and E. Maiss, 2000. Detection of $R$. solanacearum in potato tubers by polymerase chain reaction. J. Phytopathol., 148: 619-626.

15. Picard, C., C. Ponsonnet, E. Paget, X. Nesme and S. Pascal, 1992. Detection and enumeration of bacteria in soil by direct DNA extraction and polymerase chain reaction. Applied Environ. Microbiol., 10: 2717-2722. 